ceased to maintain and distribute cultures of fungi and yeasts; it is now confining its activities to bacteria and viruses. Most of the fungi, except yeasts and fungi of medical interest, from the National Collection of Type Cultures, have been transferred to the Imperial Mycological Institute, which proposes to maintain cultures of phytopathogenic, taxonomic and economic interest, provided expected financial support is forthcoming. Applications for cultures should be addressed to the Director of the Institute at Ferry Lane, Kew, Surrey. Timberrotting fungi can be obtained, as before, from the Director, Forest Products Research Laboratory, Princes Risborough, Bucks.

\section{Conference on Films in Agriculture}

THE Scientific Film Association is organising a one-day conference to be held on January 17 at the Caxton Hall, London, at which the present state and the future development of the use of films in agriculture and their place in the drive for increasing production will be discussed. The chair will be taken by Prof. J. A. Scott Watson, chief scientific and agricultural adviser to the Ministry of Agriculture and Fisheries. Mr. G. Goodman (Ministry of Agriculture) will speak on the scope, and Mr. A. Vesselo (Central Film Library) on the sources and distribution of agricultural films. Dr. W. K. Slater (senior education and advisory officer of the Ministry of Agriculture) will discuss the use of the instructional film in agriculture; Mr. R. Kenney, lecturer in agriculture, University of Reading, will deal with its use in university training and research; and $\mathrm{Mr}$. E. Anstey (Film Centre) with the making of agricultural teaching films. In the evening a show of selected British and foreign agricultural films will be given. Further information and tickets ( $£ 11 s$. each, including buffet lunch and tea) can be obtained from the Conference Secretary, Scientific Film Association, 34 Soho Square, London, W.1.

\section{Geographical Distribution of Deaths from Cancer}

THE General Register Office has initiated a series of occasional publications under the title of "Studies on Medical and Population Subjects". The purpose of the series is to present a more detailed treatment of certain important subjects than is possible in the Registrar General's Annual Statistical Review. The first publication is by Dr. Percy Stocks, and studies geographical variations in mortality from cancer of various sites (Regional and Local Differences in Cancer Death Rates. London : H.M. Stationery Office. 1s. net). One of the underlying difficulties in such a study is the uncertainty as to the accuracy of the certified cause of death, particularly in relation to inaccessible sites. It is, however, impossible to dismiss all the local differences demonstrated by Dr. Stocks as due to such variations in certification practice, and this study investigates other possible explanations. Correlations with social indices show a marked relationship with stomach cancer, but none with lung cancer. However, lung cancer mortality is closely associated with annual hours of sunshine in twenty large towns, and this suggests that a beneficial effect of sunshine or a deleterious effect of smoke may operate. A grouping of London boroughs according to their water supply is reminiscent of Farr and cholera, but is not so revealing. Dr. Stocks has brought together a great deal of information and has put forward many suggestions for more intensive research.

\section{Comet 1947n}

THIs comet was discovered in the southern hemisphere on December 8, and was described as diffuse with stellar condensation and a tail longer than $1^{\circ}$ Its magnitude was -5 , and it was moving northward. Dr. Cunningham computed an orbit from observations supplied; but as these may not have been very accurate, the orbit must be regarded as merely provisional. The elements of the orbit and an ephemeris are given below :

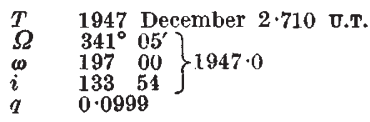

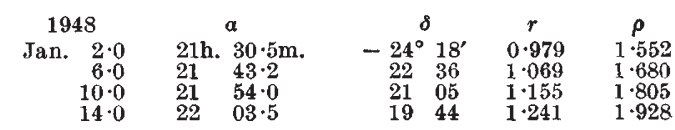

\section{The Night Sky in January}

NEw moon occurs on Jan. 11d. 07h. 44m., U.T., and full moon on Jan. $26 \mathrm{~d} .07 \mathrm{~h}$. $1 \mathrm{~lm}$. The following conjunctions with the moon take place: Jan. 8d. 14h., Jupiter $3^{\circ} \mathrm{N}$.; Jan. 14d. 04h., Venus $4^{\circ}$ N. ; Jan. 27d. 05h., Saturn $4^{\circ}$ S. ; Jan. 28d. 06h., Mars 0.6 $6^{\circ} \mathrm{S}$. Mercury, in superior conjunction on Jan. 3, becomes an evening star later and sets at $16 \mathrm{~h} .52 \mathrm{~m}$., and 18h. $15 \mathrm{~m}$., at the middle and end of the month, respectively, but the planet lies too low for good visibility. Venus, an evening star of stellar magnitude $-3 \cdot 4$, sets at $18 \mathrm{~h} .23 \mathrm{~m} ., 19 \mathrm{~h} .08 \mathrm{~m}$. and $20 \mathrm{~h}$, at the beginning, middle and end of the month, respectively, and is a conspicuous object, about 80 per cent of the illuminated disk being visible. Mars, in the constellation of Leo, is visible throughout the greater portion of the night, rising at $2 \mathrm{lh} ., 20 \mathrm{~h}$. $04 \mathrm{~m}$. and $18 \mathrm{~h} .41 \mathrm{~m}$., on Jan. 1, 15 and 31 , respectively. Jupiter is not visible until the late morning hours, its time of rising on Jan. 1 being $6 \mathrm{~h} .20 \mathrm{~m}$., and $4 \mathrm{~h} .50 \mathrm{~m}$. on Jan. 31. As the planet does not attain an altitude of $17^{\circ}$ in the latitude of Greenwich, it is not very suitably placed for observation. Saturn, in the constellation of $\mathrm{LeO}$, is visible throughout most of the night, rising at $19 \mathrm{~h} .46 \mathrm{~m}$. and $17 \mathrm{~h} .30 \mathrm{~m}$., at the beginning and end of the month, respectively. Occultations of stars brighter than magnitude 6 are as follows : Jan 3d. 05h. 35.1m., $\gamma$ Virg. m. $(D)$; Jan. 3d. 06h. 48.5m., $\gamma$ Virg. $(R)$; Jan. 17d. 19h. 45.7m., 14 Ceti $(D)$; Jan. 23d. 20h. 51.9m., 139 Taur. $(D) . \quad D$ and $R$ refer to disappearance and reappearance, respectively, and the latitude and longitude of Greenwich are assumed. In addition to these occultations of stars, Mars is occulted on Jan. 28d. $06 \mathrm{~h}$. $09 \cdot 9 \mathrm{~m}$, reappearing at $6 \mathrm{~h} .26 \cdot 3 \mathrm{~m}$. The earth is in perihelion on Jan. 2.

\section{Announcements}

VIscount FaLmouth has been elected by the governors of the Imperial College of Science and Technology to be their chairman in succession to Lord Rayleigh, whose period of office terminated on May 31, 1947.

THE Council of the British Welding Research Association has accepted an offer from Messrs. British Oxygen Company, Ltd., to provide a prize fund of $£ 100$ a year for three years. A single prize of $£ 100$ is offered in 1948 for the best paper on a research into welding or its application. Papers must be submitted on or before September 30, 1948. 